\title{
Spectrophotometric and HPLC determination of deflazacort in pharmaceutical dosage forms
}

\author{
Amarilis Scremin ${ }^{1, *}$, Monika Piazzon ${ }^{1}$, Marcos Antonio Segatto Silva ${ }^{1}$, Gislaine Kuminek ${ }^{1}$, Giane \\ Márcia Correa $^{2}$, Niraldo Paulino ${ }^{3}$, Simone Gonçalves Cardoso ${ }^{1}$
}

\begin{abstract}
${ }^{1}$ Department of Pharmaceutical Sciences, Federal University of Santa Catarina, ${ }^{2}$ Department of Health Sciences, Faculty of Pharmacy, Institute of Science, Technology and Health, The Northwest Regional University of Rio Grande do Sul, ${ }^{3}$ Group for Research and Development in Phytomedicine, Institute of Post-graduation, Bandeirante University of São Paulo
\end{abstract}

\begin{abstract}
Deflazacort (DFZ) is a glucocorticoid used as an anti-inflammatory and immunosuppressant drug. No official methods are available for DFZ determination in pharmaceutical formulations. The objective of this study was to develop, validate and compare spectrophotometric (UV and colorimetric) and highperformance liquid chromatography (HPLC) methods, for the quantitative determination of DFZ in tablets and oral suspension. For the UV method, ethanol was used as the solvent, with detection at $244 \mathrm{~nm}$. The colorimetric method was based on the redox reaction with blue tetrazolium in alkaline medium, with detection at $524 \mathrm{~nm}$. The method by HPLC was carried out using a $\mathrm{C}_{18}$ column, mobile phase consisting of acetonitrile:water $(80: 20, \mathrm{v} / \mathrm{v})$ with a flow rate of $1.0 \mathrm{~mL} \mathrm{~min}-1$ and detection at $244 \mathrm{~nm}$. The methods proved linear $(r>0.999)$, precise $(\mathrm{RSD}<5 \%)$ and accurate (recovery $>97 \%)$. Statistical analysis of the results indicated that the UV and HPLC methods were statistically equivalent, while the values obtained for the colorimetric method differed significantly from the other methods.
\end{abstract}

Uniterms: Deflazacort/quantitative determination. High performance liquid chromatography/quantitative analysis. Spectrophotometry/quantitative analysis. Medicines/quantitative analysis.

O deflazacorte (DFZ) é um fármaco glicocorticóide usado como antiinflamatório e imunossupressor. Métodos oficiais não estão disponíveis para a determinação de DFZ em formas farmacêuticas. Este estudo teve como objetivo desenvolver, validar e comparar métodos por espectrofotometria (UV e colorimetria) e cromatografia líquida de alta eficiência (CLAE), na determinação quantitativa de DFZ em comprimidos e suspensão oral. O método por UV utilizou etanol como solvente, com detecção em 244 nm. O método colorimétrico foi baseado na reação de redução com azul de tetrazólio em meio alcalino, com detecção em $524 \mathrm{~nm}$. O método por CLAE utilizou coluna $\mathrm{C}_{18}$; fase móvel constituída de acetonitrila:água (80:20, $\mathrm{v} / \mathrm{v})$, com fluxo de 1,0 mL min ${ }^{-1}$ e detecção em $244 \mathrm{~nm}$. Os métodos foram lineares $(\mathrm{r}>0,999)$; precisos ( $\mathrm{RSD}<5 \%$ ), e exatos (recuperação $>97 \%$ ). As análises estatísticas dos resultados obtidos indicaram que os métodos por UV e por CLAE foram estatisticamente equivalentes, enquanto os valores obtidos para o método colorimétrico diferiram significativamente dos demais métodos.

Unitermos: Deflazacorte/determinação quantitativa. Cromatografia líquida de alta eficiência/análise quantitativa. Espectrofotometria/análise quantitativa. Medicamentos/análise quantitativa.

\section{INTRODUCTION}

Deflazacort (DFZ) (Figure 1) is an oxazoline (1-(1,16)-21-(acetyloxy)-11-hydroxy-2-methyl-5Hpregna-1,4-dieno[17,16-d]oxazole-3,20-dione) (O’Neil,

*Correspondence: Amarilis Scremin. Centro de Ciências da Saúde, Universidade Federal de Santa Catarina, Laboratório Controle de Qualidade. 88040-900 Trindade - Florianópolis - SC, Brasil. E-mail: amarilis_paulino@yahoo.com.br
2006) derivative of prednisolone with anti-inflammatory and immunosuppressive action (Markham, Bryson, 1995). The drug has been prescribed for treatment of rheumatoid arthritis, asthma and other conditions (Biggar et al., 2006; Angelini, 2007; Ferraris et al., 2007), and is a corticosteroid with a lower risk of side effects than other available steroids (Biggar et al., 2006; Angelini, 2007; Ferraris et al., 2007; Gonzalez-Castañeda et al., 2007).

DFZ is currently available as tablets and as an oral 


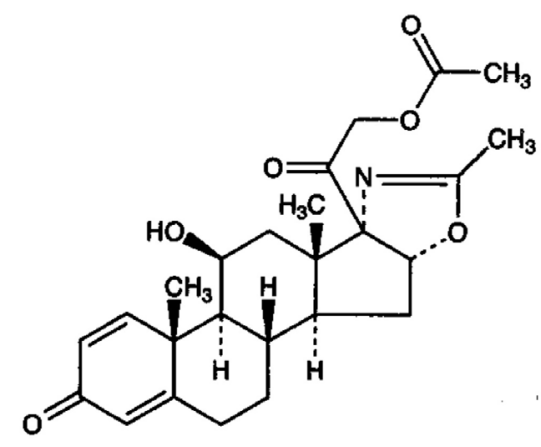

FIGURE 1 - Chemical structure of deflazacort.

suspension. Several high performance liquid chromatographic (HPLC) methods have been reported for determination of DFZ and its metabolites in biological fluids (Bernareggi et al., 1987; Santos-Montes et al., 1994; Reynolds, Burmaster, Fichmeier, 1994; Hirata et al., 1994; Möllmann et al., 1995; Rao et al., 1996; Santos-Montes, Isquierdo-Hornillos, 1999; Ifa et al., 2000). However, there is no official method for DFZ analysis in any of the pharmacopoeia. One report on a reversed-phase liquid chromatographic method with UV detection for determination of DFZ in raw material, pharmaceuticals and for in-vitro drug-dissolution studies has been published (Ozkan et al., 2003). The drug has been previously determined in tablets and compounded capsules by HPLC methods (Corrêa et al., 2007), but its determination in an oral suspension has not yet been described. Moreover, no spectrophotometric method is available for the DFZ assay in pharmaceutical formulations. The aim of this study was to develop and validate rapid, low-cost, and selective methods for routine quality control analyses of tablets and oral suspension formulations containing DFZ.

\section{EXPERIMENTAL}

\section{Chemicals and Reagents}

DFZ used as the reference standard was obtained from Pharma Nostra (99.76 \%) (São Paulo, Brazil). Tablets (30 mg) and oral suspension $\left(22.75 \mathrm{mg} \mathrm{mL}^{-1}\right)$ were purchased from the local market. The products contained the following excipients: Tablets : lactose, sucrose, povidone, crospovidone, colloidal anhydrous silica, magnesium stearate, iron oxide yellow, and iron oxide red; Suspension: crystalline cellulose carmellose sodium, sorbitol, acetic acid, benzylic alcohol, polysorbate 80 , water, propyleneglycol, simethicone, xanthan gum, ammonium glycyrrhizinate. Water was purified using a Millipore Milli-Q Gradient system (São Paulo, Brazil). Ethanol, methanol, and acetonitrile were chromatographic grade. All chemicals were analytical grade.

\section{Equipment and conditions}

A Varian UV-VIS CARY spectrophotometer and a $10 \mathrm{~mm}$ quartz cell was used to obtain all spectral and absorbance measurements. HPLC experiments were performed on a Shimadzu system (Shimadzu, Kyoto, Japan)

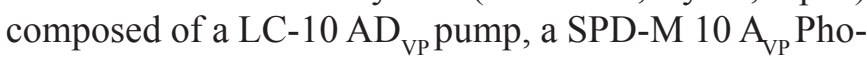
todiode Array Detector, a SCL-10 A $\mathrm{vP}_{\mathrm{P}}$ system controller, SIL-10 $\mathrm{AD}_{\mathrm{VP}}$ auto injector and a degasser module. Data were acquired and processed by Shimadzu CLASS-VP 5.032 software (Shimadzu, Kyoto, Japan). A C 18 ( $250 \mathrm{x}$ $4.6 \mathrm{~mm}$, i.d., $4 \mu \mathrm{m}$ particle size) column was used (Luna Phenomenex, Torrance, CA - USA). The mobile phase consisted of acetonitrile: water $(80: 20, \mathrm{v} / \mathrm{v})$, applied at a flow rate of $1.0 \mathrm{~mL} \mathrm{~min}^{-1}$. The injection volume was $20 \mu \mathrm{L}$ and the detection wavelength was $244 \mathrm{~nm}$.

\section{Preparation of standard solutions}

Stock solutions $\left(1 \mathrm{mg} \mathrm{mL}^{-1}\right)$ for spectrophotometric and HPLC analysis were prepared by dissolving appropriate amounts of DFZ in methanol or acetonitrile, respectively. The stock solutions were kept refrigerated $\left(2-8^{\circ} \mathrm{C}\right)$ for up to $48 \mathrm{~h}$. Aliquots of stock solution were diluted with ethanol (final concentration of $12 \mu \mathrm{g} \mathrm{mL}^{-1}$ for UV studies) or mobile phase (final concentration of $30 \mu \mathrm{g} \mathrm{mL}^{-1}$ for LC analyses). For colorimetric analysis, DFZ stock solution was diluted with ethanol to obtain a concentration of $100 \mu \mathrm{g} \mathrm{mL}-1$. Two $\mathrm{mL}$ of this solution $(200 \mu \mathrm{g})$ was transferred to a $25 \mathrm{~mL}$ volumetric flask, then $2 \mathrm{~mL}$ of $0.5 \%$ methanolic blue tetrazolium solution and $2 \mathrm{~mL}$ of $10 \%$ ethanolic tetramethylammonium hydroxide were added concomitantly. The solution was mixed, and allowed to stand in the dark for 1 hour. After dilution to volume with ethanol (final concentration of $8 \mu \mathrm{g} \mathrm{mL}^{-1}$ ), the absorbance was determined, against a blank prepared in a similar manner.

\section{Preparation of sample solution}

Samples of crushed tablets or mixed oral suspension (30 mg or $22.75 \mathrm{mg}$ of DFZ, respectively) were placed in $25 \mathrm{~mL}$ volumetric flasks. Approximately fifteen $\mathrm{mL}$ of either methanol (UV) or acetonitrile (HPLC) was added. The flasks were shaken mechanically for 15 minutes, and diluted to volume with their respectively solvents to obtain stock sample solutions. These solutions were filtered through filter paper. For the UV method, the samples were diluted in ethanol to final concentrations of $12 \mu \mathrm{g} \mathrm{mL}^{-1}$ 
(for tablets) or $14.6 \mu \mathrm{g} \mathrm{mL}^{-1}$ (for oral suspension). For the HPLC method, the samples were diluted with mobile phase to give a final concentration of $30 \mu \mathrm{g} \mathrm{mL}^{-1}$ (for tablets) or $36.4 \mu \mathrm{g} \mathrm{mL}^{-1}$ (for oral suspension). For the colorimetric assay, the samples were diluted with ethanol to obtain concentrations of $20 \mu \mathrm{g} \mathrm{mL}^{-1}$ (for tablets) or $72.8 \mu \mathrm{g} \mathrm{mL}^{-1}$ (for oral suspension). From these solutions, aliquots of $10.0 \mathrm{~mL}$ (tablets) or $2.8 \mathrm{~mL}$ (oral suspension) were transferred to a $25 \mathrm{~mL}$ volumetric flask, then $2 \mathrm{~mL}$ of $0.5 \%$ methanolic blue tetrazolium solution and $2 \mathrm{~mL}$ of $10 \%$ ethanolic tetramethylammonium hydroxide were added concomitantly. The solution was mixed, and allowed to stand in the dark for 1 hour. After dilution to volume with ethanol (final concentration of $8 \mu \mathrm{g} \mathrm{mL} \mathrm{L}^{-1}$ for tablets and $8.15 \mu \mathrm{g} \mathrm{mL}^{-1}$ for oral suspension) the absorbances were determined against a blank prepared in a similar manner.

\section{Method validation}

Each method was validated by the determination of the following operational characteristics: selectivity, linearity, limits of detection and quantification, precision and accuracy, according to the procedures described in ICH guidelines Q2 (R1) (ICH, 2005).

\section{Selectivity}

Selectivity was assessed by comparing the chromatograms (for HPLC method) or spectra (for spectrophotometric methods) obtained from the drug in a mixture containing the most commonly used excipients with those obtained from a blank sample (a solution of excipients in water without the drug).

\section{Linearity}

Calibration curves (three different days) were obtained using six concentrations of the DFZ standard solutions over the ranges given in Table 1. The results obtained were used to calculate the equation of the regression line by using the linear least-squares regression method, and the data were also evaluated by analysis of variance (ANOVA).

\section{Detection Limit (DL) and Quantification Limit (QL)}

$D L$ and $Q L$ were calculated directly from the calibration plot. The DL and QL were calculated as $3.3 \mathrm{r} / \mathrm{S}$ and $10 \mathrm{r} / \mathrm{S}$, respectively, where $\mathrm{r}$ is the standard deviation of the intercept and $\mathrm{S}$ is the slope of the calibration plot.

\section{Precision}

The repeatability (intra-day precision) of the procedures was determined by analysis of six samples of tablets or oral suspension, at equal concentrations, during the same day, under identical experimental conditions. Interday precision values were obtained by assaying freshly prepared samples of tablets or oral suspension solutions on 3 different days. DFZ contents and the relative standard deviation (R.S.D.) were calculated.

\section{Accuracy}

Accuracy was evaluated using the percent recovery obtained from analysis of samples of tablets or oral suspension spiked with known amounts of DFZ reference standard at 3 different levels. The percent recovery was calculated by the following equation (AOAC, 1990):

$$
\mathrm{R}(\%)=\frac{(\mathrm{Cs}-\mathrm{Cp})}{\mathrm{Ca}}
$$

where $\mathrm{R}(\%)$ is the percent recovery of added DFZ reference standard; Cs is DFZ concentration in the spiked sample; $\mathrm{Cp}$ is DFZ concentration in the unspiked sample; and $\mathrm{Ca}$ is the amount of DFZ reference standard added.

\section{RESULTS AND DISCUSSION}

The choice of an analytical method depends on factors such as the nature of the drug, the complexity of the sample, and the intended use of the method. For quality control in drug analysis, the simplest and fastest method is the most desirable. According to Görög, the predominant method for the assay of steroid drugs is reversed phase high performance liquid chromatography (RP-HPLC) with UV detection (Görög, 2004). However, spectrophotometric methods are also widely used because they are inexpensive and easy to perform. The spectral investigation of DFZ in different solvents (methanol, ethanol, and acetonitrile) and the influence of excipients present in the pharmaceutical formulations were also evaluated. Due to better solubility of the drug in ethanol and ethanol's lower toxicity, this diluent was chosen for the present analysis. DFZ in ethanol showed an absorption maximum at $244 \mathrm{~nm}$ (Figure 2A). The colorimetric method, which was based on the assay for steroids described in the USP Pharmacopoeia, involves the redox reaction of DFZ with tetrazolium reagent in alkaline medium which generates formazen in a quantitative manner (United States Pharmacopeia, 2007). The optimized time of the redox reaction 

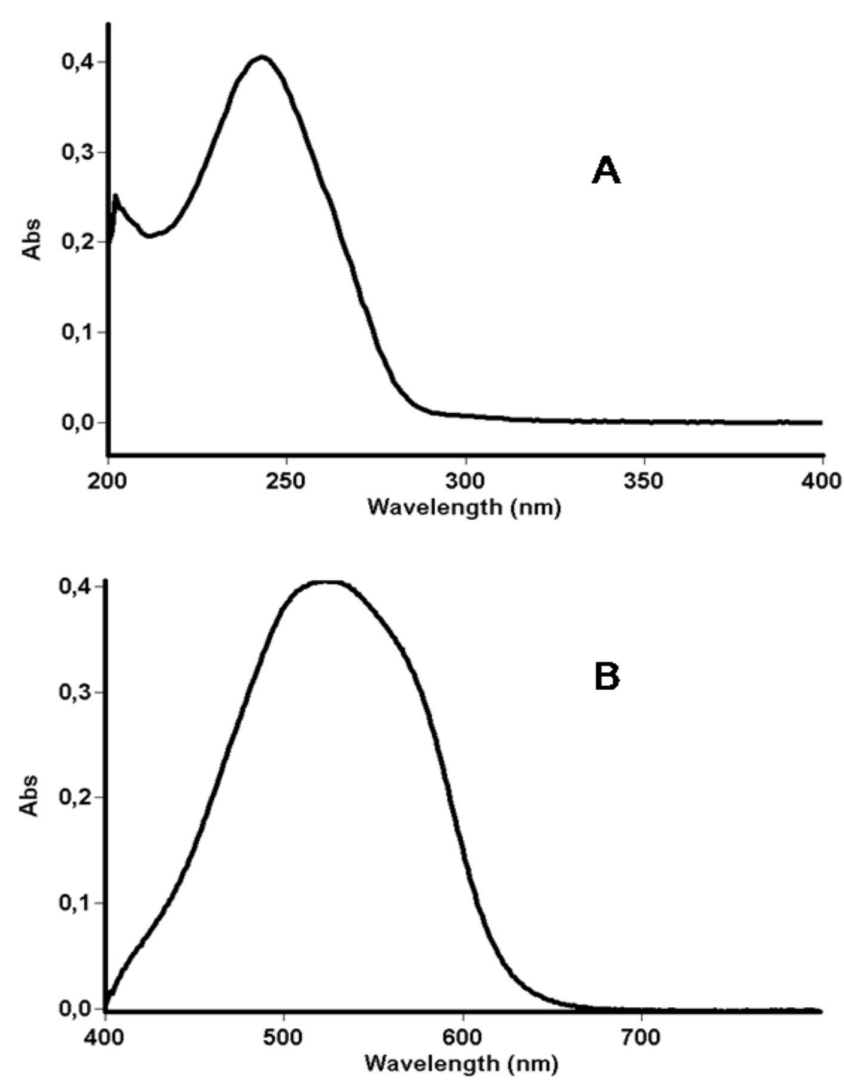

FIGURE 2 - A - UV spectrum of deflazacort reference standard solution in ethanol $\left(12 \mu \mathrm{g} \mathrm{mL}^{-1}\right)$. B - Spectrum of the redox reaction of blue tetrazolium and DFZ $\left(8 \mu \mathrm{g} \mathrm{mL}^{-1}\right)$ by colorimetric analysis.

was 1 hour, and the concentration of DFZ was determined from the absorption at $524 \mathrm{~nm}$ (Figure 2B).

The HPLC method was previously validated in our group for DFZ assay in tablets and compounded capsules (Corrêa et al., 2007). In the present paper, the HPLC method was extended for the determination of DFZ in oral suspension. Compared with the previously published HPLC method (Oskan et al., 2003), our method has the advantage of simpler mobile phase. By not using a buffered system column lifetime should be increased. A typical chromatogram of DFZ from the oral suspension is shown in Figure 3.

\section{Validation of the methods}

We observed no evidence of interference from the excipients in the methods analyzed. For spectrophotometric methods, the spectra of the samples and the DFZ reference spectrum showed the same maximum. For the HPLC method, the analytic chromatographic peak was not attributable to more than one component (peak purity test $>99 \%$ ). At equal concentrations, the peak areas of the DFZ standard and solutions of DFZ extracted from the oral suspension were identical. The methods were shown to be selective to quantify DFZ. A linear relationship was found between the DFZ concentrations and the responses (both absorbance intensity and peak area). The linearity data were validated by ANOVA, which demonstrated a significant linear regression and no significant deviation from linearity $(P=0.05)$. The regression analyses are presented in Table I. High regression coefficients $(r)$ were obtained for all three methods $(r>0.999)$.

The precision data obtained for the evaluated methods are shown in Table II. The RSD (Relative Standard Deviation) values show that all the methods exhibited good repeatability $(<5.0 \%)$ for intra and inter-day precision (BRASIL, 2003).

Accuracy was investigated by means of a standard addition experiment. Good recovery values were obtained (Table III) and ranged from 95 to $105 \%$. The validated spectrophotometric and HPLC methods were applied to the analysis of DFZ in both tablets and oral suspension.

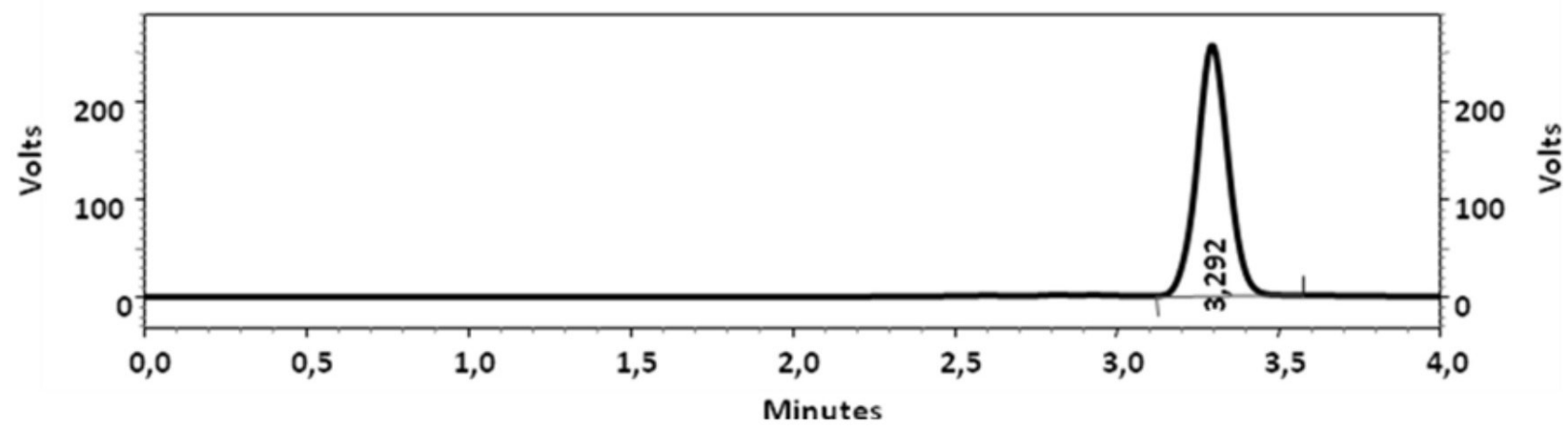

FIGURE 3 - HPLC chromatogram of DFZ obtained from oral suspension $\left(36.4 \mu \mathrm{g} \mathrm{mL}^{-1}\right), \mathrm{C}_{18}(250 \mathrm{x} 4.6 \mathrm{~mm}$, i.d., $4 \mu \mathrm{m}$ particle size) column, mobile phase consisted of acetonitrile: water $(80: 20, \mathrm{v} / \mathrm{v})$, applied at a flow rate of $1.0 \mathrm{~mL} \mathrm{~min}^{-1}$, injection volume was $20 \mu \mathrm{L}$ and elution of peaks was monitored at $244 \mathrm{~nm}$. 
TABLE I - Overview of the linearity, detection limit (DL) and quantitation limit (QL) data obtained for deflazacort by the chromatographic and spectrophotometric methods

\begin{tabular}{lccc}
\hline & \multicolumn{3}{c}{ Method } \\
\cline { 2 - 4 } Parameters & $\mathrm{UV}$ & Colorimetric & LC \\
\hline Concentration range $\left(\mu \mathrm{g} \mathrm{mL}^{-1}\right)$ & $4.0-24.0$ & $2.0-16.0$ & $5.0-50.0$ \\
Regression coefficient $(\mathrm{r})$ & 0.9990 & 0.9998 & 0.9998 \\
Slope \pm standard error & $0.0342 \pm 0.0004$ & $0.0465 \pm 0.0009$ & $41830 \pm 376.24$ \\
Intercept \pm standard error & $0.0063 \pm 0.0068$ & $0.0098 \pm 0.0085$ & $1577.4 \pm 11417$ \\
$\mathrm{DL}\left(\mu \mathrm{gL}^{-1}\right)$ & 0.12 & 0.23 & 0.18 \\
$\mathrm{QL}\left(\mu \mathrm{gL}^{-1}\right)$ & 0.37 & 0.66 & 0.55 \\
\hline
\end{tabular}

TABLE II - Precision of the evaluated methods for deflazacort determination

\begin{tabular}{|c|c|c|c|c|}
\hline \multirow[b]{3}{*}{ Method } & \multicolumn{4}{|c|}{ Oral suspension } \\
\hline & \multicolumn{2}{|c|}{ Intra-day } & \multicolumn{2}{|c|}{ Inter-day } \\
\hline & $\% \pm$ s.e.m. & $\%$ RSD & $\% \pm$ s.e.m & $\%$ RSD \\
\hline UV & $96.3 \pm 0.6$ & 2.1 & $97.9 \pm 0.8$ & 1.4 \\
\hline Colorimetric & $99.2 \pm 1.0$ & 3.5 & $100.4 \pm 1.5$ & 2.6 \\
\hline \multirow[t]{3}{*}{$\underline{L C}$} & $96.3 \pm 0.1$ & 0.4 & $95.2 \pm 0.7$ & 1.2 \\
\hline & \multicolumn{4}{|c|}{ Tablets } \\
\hline & \multicolumn{2}{|c|}{ Intra-day } & \multicolumn{2}{|c|}{ Inter-day } \\
\hline Method & $\% \pm$ s.e.m & $\%$ RSD & $\% \pm$ s.e.m & \% RSD \\
\hline UV & $97.2 \pm 0.5$ & 1.1 & $97.2 \pm 0.1$ & 0.1 \\
\hline Colorimetric & $101.6 \pm 0.9$ & 2.0 & $101.9 \pm 0.8$ & 1.3 \\
\hline $\mathbf{L C}$ & $97.7 \pm 0.6$ & 1.5 & $98.4 \pm 0.7$ & 1.2 \\
\hline
\end{tabular}

s.e.m. Standard error mean. RSD : Relative standard deviation.

TABLE III - Accuracy of the evaluated methods for deflazacort determination

\begin{tabular}{lccccccccc}
\hline & \multicolumn{3}{c}{ UV } & \multicolumn{3}{c}{ Colorimetric } & \multicolumn{3}{c}{ LC } \\
\hline Tablets & & & & & & & & & \\
Added $\left(\mu \mathrm{g} \mathrm{mL}^{-1}\right)$ & 6.0 & 12.0 & 18.0 & 4.0 & 8.0 & 12.0 & 4.0 & 8.0 & 12.0 \\
Found $\left(\mu \mathrm{g} \mathrm{m}^{-1}\right)$ & 6.06 & 12.05 & 18.12 & 3.85 & 7.98 & 12.04 & 3.98 & 7.86 & 11.77 \\
Recovery $(\%)$ & 101.0 & 100.7 & 100.6 & 97.9 & 99.8 & 100.0 & 99.5 & 98.2 & 98.1 \\
\hline Oral suspension & & & & & & & & & \\
Added $\left(\mu \mathrm{g} \mathrm{mL}^{-1}\right)$ & 2.0 & 4.0 & 8.0 & 2.0 & 4.0 & 6.0 & 2.5 & 5.0 & 7.5 \\
Found $\left(\mu \mathrm{g} \mathrm{mL}^{-1}\right)$ & 1.97 & 3.98 & 7.85 & 1.94 & 3.90 & 5.90 & 2.47 & 5.09 & 7.54 \\
Recovery $(\%)$ & 98.7 & 99.5 & 98.2 & 96.9 & 98.3 & 98.4 & 97.4 & 100.4 & 98.9 \\
\hline
\end{tabular}

Although all three methods have shown precision and accuracy within the required criteria, the results obtained by the colorimetric method were found to be higher than the other methods (at least 3.5\% above the others). The ANOVA test was also applied and revealed statistically significant differences among the results obtained by the three individual analytical methods at a confidence level of 0.05 . Tukey's multiple comparison test demonstrated that the results obtained by the HPLC and UV methods for both tablets and oral suspension were statistically equivalent ( $p>0.05)$. However, the values obtained for the colorimetric method differed significantly 
from those obtained by HPLC and UV spectrophotometric methods $(p<0.05)$, and indicated that the colorimetric method was not superior to the UV method based on the natural absorption spectrum of DFZ. The rapid assay times of the UV spectrophotometric method and the good precision for this procedure are additional advantages of this method compared with the colorimetric method (Görög, 2005). The HPLC method was more selective, and could be applied successfully in stability studies of DFZ in pharmaceutical formulations.

\section{CONCLUSION}

The proposed spectrophotometric and HPLC methods were linear, accurate and specific. The results showed that the UV spectrophotometric and HPLC methods were statistically equivalent. However, the values obtained by the colorimetric assay differed significantly from the other methods, making this procedure less satisfactory than the UV spectrophotometric and HPLC methods. Since the UV spectrophotometric and HPLC methods are precise and simple, they may be successfully applied in quality control analysis of DFZ in tablets and oral suspension.

\section{REFERENCES}

ANGELINI, C. The role of corticosteroids in muscular dystrophy: a critical appraisal. Muscle Nerve, v.4, p.424435, 2007.

ASSOCIATION OF ANALYTICAL COMMUNITIES INTERNATIONAL. AOAC. Official Methods of Analysis. 15.ed. Arlington: AOAC INTERNATIONAL, 1990. p.xvii.

BERNAREGGI, I. A.; POLETT P.; ZANOLO, G.; ZERILLI, L. F. Simultaneous determination of the two main metabolites of deflazacort in human plasma by high-performance liquid chromatography. J. Pharm. Biomed. Anal., v.5, p.177-181, 1987.

BIGGAR, W.D.; HARRIS, V.A.; ELIASOPH, L.; ALMAN, B. Long-term benefits of deflazacort treatment for boys with Duchenne muscular dystrophy in their second decade. Neuromuscul. Disord., v.16, p.249-255, 2006.

BRASIL, Resolução - RE nº 899, de 29 de maio de 2003, Guia para a validação de métodos analíticos e bioanalíticos. Diário Oficial União, ANVISA - Agência Nacional de Vigilância Sanitária, on line. Available at: $<$ http://www. anvisa.gov.br/legis/resol/2003/re/899_03re.htm>. Accessed on: 19 mar. 2007.
CORRÊA, G. M.; BELLÉ, L. P.; BAJERSKI, L.; BORGMANN, S. H. M.; CARDOSO, S. G. Development and validation of a reversed-phase HPLC method for the determination of deflazacort in pharmaceutical dosage forms. Chromatographia, v.65, p.591-594, 2007.

FERRRARIS, J. R.; PASQUALINI, T.; ALONSO, G.; LEGAL, S.; SORROCHE, P.; GALICH, A. M.; JASPER, H. Effects of deflazacort vs. Methylprednisone: a randomized study in kidney transplant patients. Pediatr. Nephrol., v.5, p.734$741,2007$.

GONZALEZ-CASTAÑEDA R. E.; CASTALLANOSALVARADO F. A.; FLORES-MARQUEZ M. R.; GONZALEZ-PEREZ O.; LUQUIN S.; GARCIAESTRADA J.; RAMOS-REMUS C. Deflazacort induced stronger immunosuppression than expected. Clin. Rheumatol., v.6, p.935-940, 2007.

GÖRÖG, S. Recent advances in the analysis of steroid hormones and related drugs. Anal. Sci., v.20, p.67-82, 2004.

GÖRÖG, S. The sacred cow: the questionable role of assay methods in characterizing the quality of bulk pharmaceuticals. J. Pharm. Biomed. Anal., v.36, p.931937, 2005.

HIRATA, H.; KASAMA T.; SAWAI Y.; FIKE, R. R. Simultaneous determination of deflazacort metabolites II and III, cortisol, cortisone, prednisolone and prednisone in human serum by reversed-phase high performance liquid chromatography. J. Chromatogr. B Biomed. Appl., v.658, p.55-61, 1994.

IFA D. R.; MORAES M. E.; MORAES M. O.; SANTAGADA V.; CALIENDO G.; DE NUCCI G. Determination of 21-hydroxydeflazacort in human plasma by highperformance liquid chromatography/atmospheric pressure chemical ionization tandem mass spectrometry. Application to bioequivalence study. J. Mass Spectrom., v.35, p.440445, 2000.

INTERNATIONAL CONFERENCE ON HARMONIZATION (ICH). Text on validation of analytical procedure: methodology: Q2(R1), 2005. Available at: http://www.ich. org. Accessed on: 24 jul. 2007.

MARKHAM A.; BRYSON H. M. Deflazacort. A review of its pharmacological properties and therapeutic efficacy. Drugs, v.50, p.317-333,1995. 
MÖLLMANN, H.; HOCHHAUS G.; ROHATAGI S.; BARTH J.; DERENDORF H. Pharmacokinetic/ pharmacodynamic evaluation of deflazacort in comparison to methylprednisolone and prednisolone. Pharm. Res., v.12, p.1096-1100, 1995.

O'NEIL, M. J. The Merck Index Encyclopedia of chemicals, drugs and biologicals. 14 ed. New York: Merck \&co. 2006. $2520 \mathrm{p}$.

OZKAN, Y.; SAVASER, A.; TAS, C.; USLU, B.; OZKAN, S. A. Drug dissolution studies and determination of deflazacort in pharmaceutical formulations and human serum samples by RP-HPLC. J. Liq. Chromatogr. Relat. Technol., v.26, p.2141-2156, 2003.

RAO, N.; BHARGAVA, V. O.; REYNOLDS, D. L.; ELLER, M. G.; WEIR, S. J. An investigation of the dose proportionality of deflazacort pharmacokinetics. Biopharm. Drug. Dispos., v.17, p.753-760, 1996

REYNOLDS, D. L.; BURMASTER, S. D.; EICHMEIER, L. S. Quantitative determination of 21-hydroxy-deflazacort in human plasma using gradient semi-microbore liquid chromatography. Biomed. Chromatogr., v.8, p.230-235, 1994.
SANTOS-MONTES, A.; GONZALO-LUMBRERAS, R.; GASCO-LOPES, A. I.; ISQUIERDO-HORNILLOS, R. Extraction and High-performance liquid chromatography separation of Deflazacort and it metabolite 21-hydroxydeflazacort. Application to urine samples. $J$. Chromatogr. B Biomed. Appl., v.657, p.248-253, 1994.

SANTOS-MONTES, A.; IZQUIERDO-HORNILLOS, R.; Optimization of separation of a complex mixture of natural and synthetic corticoids by micellar liquid chromatography using sodium dodecyl sulphate. Application to urine samples. J. Chromatogr. B Biomed. Sci. Appl., v.724, p.5363, 1999.

UNITED STATES PHARMACOPEIA. 30.ed. Rockville: United States Pharmacopoeial Convention, 2007. Available at: http://www.usp.org/USPNF/. Accessed on: 05 apr. 2008.

Received for publication on $14^{\text {th }}$ May 2009 Accepted for publication on $22^{\text {nd }}$ November 2009 